\title{
MASNUE: CHICAGO
}

\section{AMTRRK PRELUDE}

The train takes off in slo-moparallel with a cop down the block.

Strange that the lights and the arms are for me.

I've seen the river from every other angle.

Now a black tangle, a bus parked on the gravel, glint of water visible, now hidden.

Flat tar rooftops oily with rain, Mr. Paint, the International Casket Co. In a track several cars deep, the metal sprouts into maze, coal trains shoulder to shoulder, blur of green.

If a river could be a desert soaking in radiation, rippled swamp.

Sneaking up on the towns, we're the trolls under the bridge, "Class of 66" sprayed in red.

Sheer rocks are striped gold-a prehistoric loch, shores wound into foggy braids, crunch rock. 
A little white statue waves at us from a cemetery gate.

A town lies in a row, a furrow ploughed below the iron cliffs.

It's looked like Wisconsin for a long time.

I don't recognize my state.

Nature's built fortresses over the town,

walls spraypainted with rust.

God's going to fall down that hill.

\section{HIGH RISE}

Row of streetlight 16 stories below, a line of light radiates from the spike on my halo.

I could set my cup on the coffee table of the roof next door, set between the vents.

Steam pours from the Academy, whiter at night, but thick even when clear. A green churn of light seems to balloon from a distant window, like the building is sticking out its tongue.

I can't tell the ground from the roof.

Only height erases the sound from the street. 


\section{GREEN MORAY}

Memories made of fish.

A beautiful silver coat, another with scales of grey velvet snakeskin.

Yellow and white stripes with marble blue eyes.

In fluorescent nature, coral blowing as if in a breeze, blue starfish glowing stuck to the glass.

The softshell turtle, the chocolate chip sea star, the no-bodied moon jelly, see-through blue.

Sturgeons look like they've been stitched up the sides, cotton leaking through the scarred braided tissue.

Orange plumose anemone, like a fluffy fiberoptic novelty lamp.

Small banana fingers ripple in waves, blue fingertipped, a wallpaper of the bright purple lichen and amethyst moss.

Blue silk bulbs, pelts yellow and fuchsia, speckling, quivering scarlet threadtips. 


\section{LAKE}

Outside ducks flirt on the lake, black pigeons twist their opal heads, water aqua deepened to green slaps the concrete.

The totem pole is a crucifix with wings.

A soap-shaped pool in the soap dish.

Someone said something about

a fish and a pond.

The sky thins into paler layers,

thin fronds of shark.

At this proximity I take the clouds personally

The roof looks lined with felt.

Ghost of a velvety stingray glides triangular out of the milky yellow horizon. The sun is gone but it's not dark, a penny candle of light flung up this high.

The water darkens as the air grows brighter.

At first they almost meet in pale.

The color sharpens as it fades above 


\section{ARBORETUM}

Pheasant-striped butterflies,

bright, creamy, orangesicle butterfly moving like a hummingbird, an albino monarch, perfect snow-white instead of the orange of home, paperthin wings, nosing into the lantana, outerspace cluster of flowerbells, a shadow of nervous wing, indigo and pink.

Taffeta plant, Midnight ginger, leaves almost black, the Lipstick Palm, stem like bright red bamboo bursting into palm.

Letters kink into sigils rather than words.

It's beautiful from here. Where does the world go wrong? The lake turns blue: as above, so below.

The Salvation Army covered with "No loitering" signs.

A handprint of oil splash on the asphalt, everything for rent on Bittersweet Street. 


\section{PLAZA MARKET}

In one ornate and one brown block, a courtyard dropped from a great spike of height. Stone-encrusted benches like towers of birdseed.

Where $1=1$.

Across the river, a building seems bent inward and melted. Height reflects in height, needlework outside. The el isn't all elevated.

The water not dirty but impenetrable green.

\section{STREET}

A woman hollers at the bus stop that

Jesus gave us a beautiful day.

There'll be problems tomorrow, problems next week, but today is a beautiful day. 